\title{
Effects of Grit Blasting on Surface Properties of Adhesive Bonded Adherents
}

Petr Valášek, Miroslav Müller

Department of Material Science and Manufacturing Technology, Faculty of Engineering, Czech University of Life Sciences Prague. Kamýcká 129, 165 21, Prague. Czech Republic. E-mail: valasekp@tf.czu.cz, muller@tf.czu.cz

\begin{abstract}
A mechanical treatment of an adherent before an application of adhesives is one of key factors influencing resultant strength of an adhesive bond. A grit blasting belongs among one of the most often used methods of the surface treatment. A resultant structure of blasted adherent and also parameters of the surface roughness can be changed during the blasting by a suitable choice of many parameters among which a material and a size of abrasive particles, a distance of an air jet and a blasted material, a size of the jet, an air pressure and an angle of abrasive particles impact can be ranked. This experiment describes an injector system of grit blasting using basic abrasives - corundum and glass ballotini. During grit blasting of common steel adherent it came to the change of the impact angle of the abrasive particle in a range from $75^{\circ}$ (a perpendicular angle) to $10^{\circ}$. Different impact angle led to different roughness parameters and to various structure of the adherent surface which was evaluated by an electron microscopy. Subsequently, it came to experimental description of the strength of adhesive bonds which were created by adherents whose surface was grit blasted under various impact angles of abrasive particles.
\end{abstract}

Keywords: Ballotini, corundum, erosive wear, lap-shear strength.

\section{Acknowledgement}

The results were supported by the grant IGA TF 2015 (31140/1312/3106).

\section{References}

[1] SHAHID, M., HASHIM, S. A. (2002). Effect of surface roughness on the strength of cleavage joints. In: International Journal of Adhesion \& Adhesives, Vol. 22, No. 3, pp. 235 - 244.

[2] POORNA CHANDER, K. et al. (2009). Effects of grit blasting on surface properties of steel substrates. In: Materials \& Design, Vol. 30, No. 8, pp. $2895-2902$.

[3] BITTER, J. G. A. (1963). A study of erosion phenomena part I. In: Wear, Vol. 6, No. 1, pp. 5 - 21.

[4] LANCASTER, J. K. (1990). Material-specific wear mechanisms: relevance to wear modeling. In: Wear, Vol. 141, No. 1, pp. $159-183$.

[5] WANG, Y., YANG, Z. (2009). Coupled finite element and meshfree analysis of erosive wear. In: Tribology International, Vol. 42, No. 2, pp. $373-377$.

[6] HUTCHINGS, I. M. (1981). A model for the erosion of metals by spherical particles at normal incidence. In: Wear, Vol. 70, No. 3, pp. $269-281$.

[7] HARRIS, A. F., BEEVERS, A. (1999). The effects of grit-blasting on surface properties for adhesion. In: International Journal of Adhesion \& Adhesives, Vol. 19, No. 6, pp. $445-452$.

[8] VARACALLE, D. J. et al. (2006). Effect of grit-blasting on substrate roughness and coating adhesion. In: Journal of thermal spray technology, Vol. 15, No. 3, pp. $348-355$.

[9] ŤAVODOÁ, M. (2013). The surface quality of materials after cutting by abrasive water jet evaluated by selected methods. In: Manufacturing Technology, Vol. 13, No. 2, pp. $236-241$.

[10] NOVÁK, M. (2012). Surfaces with high precision of roughness after grinding. In: Manufacturing Technology, 12 , pp. $66-70$.

[11] MÜLLER, M. (2015). Influence of loading speed on a change of parameters of adhesive bonds based on cyanoacrylates. In: Research Agricultural Engineering, Vol. 61, No. 4, pp. 177 - 182.

[12] MÜLLER, M. (2015). Research on Surface Treatment of Alloy AlCu4Mg Adhesive bonded with Structural Single-component Epoxy Adhesives. In: Manufacturing Technology, Vol. 15, No. 4. pp. 629 - 633.

[13] BORSELLINO, C., DI BELLA, G., RUISI, V.F. (2009). Adhesive joining of aluminium AA6082: the effects of resin and surface treatment. In: International Journal. Adhesion \& Adhesives, Vol. 29, pp. 36 - 44.

[14] ELBINGA, F., ET AL. (2003). Dry ice blastingas pretreatment of aluminum surfaces to improve the adhesive strength of aluminum bondingjoints. In: International Journal of Adhesion \& Adhesives, Vol. 23, pp. 69 - 79. 
[15] ELBINGA, F., ANAGREHB, N., DORNA, L., ULMANNA, E. (1999). Dry ice blastingas pretreatment of aluminum surfaces to improve the adhesive strength of aluminium bonding joints. In: International Journal of Adhesion \& Adhesives, Vol. 23 pp. $69-79$.

[16] RUGGIERO, A., et al. (2015). Engineering Tribo-mechanical characterization of reinforced epoxy resin under dry and lubricated contact conditions. In: Composites Part B, 79, pp. $595-603$.

[17] RUGGIERO, A., et al. (2015). Friction and wear behaviors of Al/Epoxy Composites during Reciprocating Sliding tests. In: Manufacturing Technology, Vol. 15, No. 4, pp. $684-689$.

[18] VALÁŠEK, P., MÜLLER, M. (2013). Polyurethane resins filled with inorganic waste particles. In: Manufacturing Technology, Vol. 13, No. 2, pp. $241-247$.

[19] VALÁŠEK, P., MÜLLER, M. (2013). Polymeric composite based on glass powder - Usage possibilities in agrocomplex. In: Scientia Agriculturae Bohemica, No. 2, pp. 107 - 112.

\section{Paper number: M2016254}

Copyright (C) 2016. Published by Manufacturing Technology. All rights reserved. 